\title{
Estimation of genetic parameters for mid-infrared-predicted lactoferrin and milk fat globule size in Holstein cattle
}

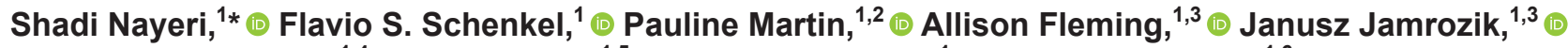 \\ Francesca Malchiodi, ${ }^{1,4} \odot$ Luiz F. Brito, ${ }^{1,5} \odot$ Christine F. Baes, ${ }^{1} \odot$ Mehdi Sargolzaei, $^{1,6}$ and Filippo Miglior ${ }^{1} \odot$ \\ ${ }^{1}$ Centre for Genetic Improvement of Livestock, Department of Animal Biosciences, University of Guelph, Guelph, ON, N1G 2W1, Canada \\ ${ }^{2}$ Génétique Animale et Biologie Intégrative (GABI), Institut National de la Recherche Agronomique (INRA), AgroParisTech, \\ Université Paris-Saclay, Jouy en Josas, 75338, France \\ ${ }^{3}$ Canadian Dairy Network, Guelph, ON, N1K 1E5, Canada \\ ${ }^{4}$ Semex Alliance, Guelph, ON, N1H 6J2, Canada \\ ${ }^{5}$ Department of Animal Sciences, Purdue University, West Lafayette, IN 47907 \\ ${ }^{6}$ Select Sires Inc., Plain City, OH 43064
}

\begin{abstract}
Lactoferrin (LF) and milk fat globule (MFG) are 2 biologically active components of milk with great economical and nutritional value in the dairy industry. The objectives of this study were to estimate (1) the heritability of mid-infrared (MIR)-predicted LF and MFG size (MFGS) and (2) the genetic correlations between predicted LF and MFGS with milk, fat, and protein yields, fat and protein percentages, and somatic cell score in first-parity Canadian Holstein cattle. A total of 109,029 test-day records from 22,432 cows and 1,572 farms for MIR-predicted LF and 109,212 test-day records from 22,424 cows and 1,559 farms for MIR-predicted MFGS were used in the analyses. Four separate 5 -trait random regression test-day models were used. The models included days in milk, herd test date, and a polynomial regression on DIM nested in age-season of calving classes as fixed effects, random polynomial regressions on DIM nested in herd-year of calving, animal additive genetic and permanent environment classes, and a residual effect. Regression curves were modeled using orthogonal Legendre polynomials of order 4 for the fixed age-season of calving effect and of order 5 for the random effects. Moderate overall heritability estimates of 0.34 and 0.46 were estimated for the MIR-predicted LF and MIR-predicted MFGS, respectively. These heritability estimates were similar to the ones estimated for the direct measure of MFGS in a previous study. The genetic correlations between predicted MFGS and fat percentage (0.53) and between predicted LF and protein percentage (0.41) were both
\end{abstract}

Received April 23, 2019.

Accepted October 30, 2019.

*Corresponding author: snayeri@uoguelph.ca moderate and positive. Predicted LF and somatic cell score showed a weaker correlation (0.06) compared with other studies. The moderate genetic correlation between MIR-predicted MFGS and fat percentage and between MIR-predicted LF and protein percentage suggests that MIR predictions of MFGS and LF are not simply a function of the amount of fat and protein percentage, respectively, in the milk (i.e., the prediction equations are not simply predicting fat or protein percentages). Thus, these MIR-predicted values may provide additional information for selecting for fine milk components in Holstein cattle.

Key words: genetic parameter, mid-infraredpredicted, lactoferrin, milk fat globule size

\section{INTRODUCTION}

Milk composition is economically and nutritionally important for both dairy producers and consumers. Milk fat is dispersed in milk in the form of small globules surrounded by a milk fat globule membrane (MFGM) that is created during secretion in the epithelial cells of the mammary gland (Smoczyński et al., 2012; Fleming et al., 2017a). These fat globules comprise 3 layers made of proteins, glycoproteins, enzymes, nonpolar and polar lipids, and phospholipids (Keenan and Mather, 2009), whereas the core of the milk fat globule (MFG) is mainly triglycerides (Wiking et al., 2004). The MFGM is also a rich source of membrane proteins, and identification of several proteins, including CD14, toll-like receptor 2, and toll-like receptor 4, on the MFGM suggests a significant role for the mammary gland in detecting an infection (Reinhardt and Lippolis, 2006). The size of MFG ranges from 0.2 to 15 $\mu \mathrm{m}$ (Smoczyński et al., 2012), with an average diameter of 2.5 to $4.6 \mu \mathrm{m}$ in bovine milk (Fleming et al., 2017a). The average diameter of MFG affects both cheese yield 
and the water content of cheeses (Martini et al., 2008). It has been reported that fatty acid composition of the MFGM is different from the overall milk fat and from the core of the globules (Wiking et al., 2004; MesilatiStahy et al., 2011). Additionally, increased fat secretion has been shown to be linked to larger fat globules in milk (Wiking et al., 2004). This is of paramount interest for consumers because the fatty acid profile of food has major effects on human health and on the risk of developing chronic and cardiovascular disease (Vannice and Rasmussen, 2014). Therefore, the structure, size of fat globules, and their mutual relations have important nutritional implications for the human diet.

Lactoferrin ( $\mathbf{L F}$ ) is an $80-\mathrm{kDa}$ iron-binding glycoprotein that is found in milk and other fluids of the body, including saliva, tears, bile, mucosa secretions, and blood (Wakabayashi et al., 2006). This protein is also synthesized by granulocytes and mammary epithelial cells in response to the growth of bacteria (Kaminski et al., 2006). Milk LF plays an important role in the defense mechanism of the mammary gland in lactating dairy animals (Cheng et al., 2008). This bioactive molecule can inhibit the growth of gram-negative bacteria through an iron-binding function or by directly killing certain bacterial strains (Weinberg, 1978; Bellamy et al., 1992; Rainard and Riollet, 2006). Lactoferrin concentration in milk is a trait of interest not only because of its immunological function in the mammary of dairy cattle but also due to other functions and pleiotropic effects on different traits in mammals (Ward et al., 2005). For example, bovine LF protein is known for its anti-inflammatory and antioxidant abilities and inhibitory action on cell proliferation (Tomita et al., 2002; Legrand et al., 2005; Pan et al., 2007). It also has been reported to have an inhibitory effect on several types of cancer in humans (Pan et al., 2007; Tsuda et al., 2010; Duarte et al., 2011).

Routine determination of MFG size (MFGS) and LF is currently not feasible due to the analytical time, cost, and complexity of the requirement of fresh milk for MFGS measurements (Fleming et al., 2017b). Midinfrared spectroscopy, however, has been recognized as a powerful tool for phenotyping traditional and novel traits at a low cost on a large scale through regular milk recording (de Roos et al., 2007; Rutten et al., 2009; Bonfatti et al., 2011; McParland et al., 2011; De Marchi et al., 2014). Even with a lower coefficient of determination of validation or cross-validation, midinfrared (MIR)-based predictions can still be very useful indicator traits in animal breeding, especially if they show high genetic correlations with the reference traits (McParland et al., 2015). In this context, the objectives of this study were to estimate (1) the heritability of MIR-predicted LF ( $\mathbf{L F}_{\text {MIR }}$ ) and MIR-predicted MFGS
$\left(\mathbf{M F G S}_{\mathrm{MIR}}\right)$ and (2) the genetic correlations between the MFGS $_{\text {MIR }}$ and $\mathrm{LF}_{\mathrm{MIR}}$ with milk, fat and protein yields, fat and protein percentages, and SCS in firstparity Canadian Holstein cattle.

\section{MATERIALS AND METHODS}

\section{Data}

Milk MIR spectral data were obtained during routine milk recording from 1 of 2 MilkoScan FT6000 spectrometers (Foss, Hillerød, Denmark) at CanWest DHI (Guelph, ON, Canada) or Valacta (Sainte-Anne-de-Bellevue, QC, Canada) milk laboratories and were stored in a database. The spectral data were collected between January 2013 and July 2017. Historical spectra were standardized across machines and time according to the methods described by Bonfatti et al. (2017). The database contained a total of 2,938,621 spectra of individual milk samples from Holstein cows. Prediction equations developed by Fleming et al. (2017a) for volume moment mean MFGS and by Fleming et al. (2018) for LF were applied to the historical spectra. Given the previously reported prediction accuracy, hereafter $\mathrm{LF}_{\mathrm{MIR}}$ and MFGS $_{\text {MIR }}$ should be considered to be indicator traits for the actual LF and MFGS traits rather than precise predictions. The data editing to select cows and herds for the genetic analyses was performed as described in Narayana et al. (2017). The initial data set of MFGS and $\mathrm{LF}_{\mathrm{MIR}}$ had 2,938,621 test-day records from 731,944 Holstein cows in 7,387 herds. Only test-day records between 5 and 305 DIM were considered for the genetic analyses (2,523,776 records); from this, several missing values and noninformative records (missing records for all the traits) were removed and 2,523,526 records were considered for the next step. From the first-lactation animals, only 394,348 cows with a calving age between 19 and 43 mo were selected; further editing was implemented by considering only animals that had their first test day within their first 50 DIM. In addition, records were deleted for a given herd $\times$ test day if fewer than 4 records were available. The last 2 criteria were applied in a loop iteration until a constant number of test-day MFGS ${ }_{\text {MIR }}$ and $\mathrm{LF}_{\mathrm{MIR}}$ records were achieved. The final data set included 109,029 records from 22,432 cows and 1,572 herds (105,737 pedigree animals) for $\mathrm{LF}_{\mathrm{MIR}}$ and 109,212 records from 22,424 cows and 1,559 herds (with 105,070 pedigree animals) for MFGS $_{\text {MIR }}$. Test-day production records for milk, fat, and protein yields, fat and protein percentages, and SCC were obtained from the Canadian Dairy Network (Guelph, ON, Canada) for the test-day records with $\mathrm{LF}_{\mathrm{MIR}}$ and $\mathrm{MFGS}_{\mathrm{MIR}}$ predicted. The SCC was log-transformed to SCS according to the formula proposed by Ali and Shook (1980). 


\section{Statistical Model}

Four separate 5-trait random regression test-day models were used for the genetic analyses. The analyses were performed for the following combinations of traits: (1) $\mathrm{LF}_{\mathrm{MIR}}$, milk yield, fat and protein percentages, SCS; (2) $\mathrm{LF}_{\mathrm{MIR}}$, milk, fat, and protein yields, SCS; (3) MFGS $_{\text {MIR }}$, milk, fat, and protein yields, SCS; and (4) MFGS $_{\text {MIR }}$, milk yield, fat and protein percentages, SCS. The model used for the genetic analyses was described by Narayana et al. (2017). The model considered for all the traits is expressed in matrix notation by the equation

$$
\mathbf{y}=\mathbf{X}_{\mathbf{c}} \mathbf{c}+\mathbf{X}_{\mathrm{b}} \mathbf{b}+\mathbf{Z}_{\mathbf{h}} \mathbf{h}+\mathbf{Z}_{\mathbf{a}} \mathbf{a}+\mathbf{Z}_{\mathbf{p}} \mathbf{p}+\mathbf{e},
$$

where $\mathbf{y}$ is a vector of observations (milk $\mathrm{LF}_{\mathrm{MIR}}$ or MFGS $_{\text {MIR }}$ and other milk components in this study); $\mathbf{c}$ is a vector of fixed effects of herd test day and DIM (300 classes); $\mathbf{b}$ is a vector of coefficients of the fixed regression on DIM nested within age-season of calving classes (25 ages and 4 seasons); $\mathbf{h}$ is a vector of coefficients of the random regression on DIM nested within herd-year of calving classes (4 years and 1,572 or 1,559 herds for $\mathrm{LF}_{\mathrm{MIR}}$ or MFGS $\mathrm{SIR}_{\mathrm{MI}}$, respectively); $\mathbf{a}$ is a vector of random regression coefficients for animal genetic effects; $\mathbf{p}$ is a vector of random regression coefficients for permanent environment effects; $\mathbf{e}$ is a vector of residuals; and $\mathbf{X}_{\mathbf{c}}, \mathbf{X}_{\mathrm{b}}, \mathbf{Z}_{\mathrm{h}}, \mathbf{Z}_{\mathrm{a}}$, and $\mathbf{Z}_{\mathrm{p}}$ are incidence matrices assigning observations to the effects. Regression curves were modeled using orthogonal Legendre polynomials of order 4 for the fixed age-season of calving effect and using orthogonal Legendre polynomials of order 5 for the random effects, as defined by Jamrozik et al. (2002). Expectations and covariance structure for the random effects were given by

$$
\begin{gathered}
\mathbf{e}(\mathbf{y})=\mathbf{X}_{\mathbf{c}} \mathbf{c}+\mathbf{X}_{\mathbf{b}} \mathbf{b}, \mathbf{E}(\mathbf{h})=0, \mathbf{E}(\mathbf{a})= \\
0, \mathbf{E}(\mathbf{p})=0, \mathbf{E}(\mathbf{e})=0
\end{gathered}
$$

and

$$
\mathrm{V}(\mathbf{h})=\mathbf{I} \otimes \mathbf{Q}_{0}, \mathrm{~V}(\mathbf{a})=\mathbf{A} \otimes \mathbf{G}_{0}, \mathrm{~V}(\mathbf{p})=\mathbf{I} \otimes \mathbf{P}_{0}, \mathrm{~V}(\mathbf{e})=\mathbf{E},
$$

where $\mathrm{V}$ is variance; $\mathbf{I}$ is the identity matrix; $\mathbf{A}$ is the additive genetic relationship matrix; $\mathbf{E}$ is a blockdiagonal residual (co)variance matrix within and across traits; $\mathbf{Q}_{0}$ is a (co)variance matrix for herd-year regression coefficients within and among traits; $\mathbf{G}_{0}$ is a (co)variance matrix of genetic regression coefficients within and among traits; $\mathbf{P}_{0}$ is a (co)variance matrix for permanent environment regression coefficients within and among traits; and $\otimes$ is the Kronecker prod- uct operator. Residual (co)variances within trait were assumed to be heterogeneous across 20 intervals of 15 DIM (5-20, 21-35, 36-50, . ., 291-305 DIM). Residuals among traits on the same test day were allowed to be correlated. All residual correlations among traits on different test days were assumed to be 0 . All random effects were assumed to be normally distributed. Variance components were estimated by Bayesian methods via Gibbs sampling using customized Fortran software (written by J. Jamrozik, Canadian Dairy Network, Guelph, ON, Canada). For additive genetic, herd-year of calving, and permanent environment effects, normal prior distributions were used. Prior distributions for (co)variances and fixed effects were as in Narayana et al. (2017). The Gibbs sampler was run for 300,000 rounds, and the first 10,000 were discarded as a burning period. A thinning interval of 50 rounds was used to retain sampled values; thus, 5,800 samples were used to estimate the posterior means of the (co)variance components. Visual inspection of trace plots for selected covariances was performed to monitor convergence. Daily heritability estimates were defined as the ratio of genetic variance to the sum of genetic, permanent environment, herd-year of calving, and residual variances for each DIM from 5 to 305 , and the overall heritability was the mean value across the entire lactation.

\section{RESULTS AND DISCUSSION}

\section{Descriptive Statistics}

Descriptive statistics for the examined traits in the edited data set are given in Table 1 . The mean values for $\mathrm{LF}_{\mathrm{MIR}}$ and $\mathrm{MFGS}_{\mathrm{MIR}}$ were $1.49 \pm 0.194(\mathrm{log})$ and $4.15 \pm 0.392 \mu \mathrm{m}$, respectively. The mean value for $\mathrm{LF}_{\mathrm{MIR}}$ was lower than the value reported by Arnould et al. (2009) in bovine milk; however, the trait unit used in their study was different from that used in this study. The mean value reported for $\mathrm{MFGS}_{\mathrm{MIR}}$ in this study was within the range reported in a previous study by Martini et al. (2017) carried out on bovine milk. The mean $\mathrm{MFGS}_{\mathrm{MIR}}$ value in this study was also similar to the mean of the directly measured MFGS in Fleming et al. (2017a).

\section{Heritability Estimates}

The averages of the heritability estimates over the entire lactation for $\mathrm{LF}_{\mathrm{MIR}}$ and $\mathrm{MFGS}_{\mathrm{MIR}}$ are shown in Table 2 . The daily averages of the heritability estimates from the 2 multivariate analyses for milk $\mathrm{LF}_{\mathrm{MIR}}$ and MFGS $_{\mathrm{MIR}}$ were 0.34 (posterior $\mathrm{SD}=0.001$ ) and 0.46 (posterior $\mathrm{SD}=0.006$ ), respectively. The heritability obtained for $\mathrm{LF}_{\mathrm{MIR}}$ in this study was higher than that 
Nayeri et al.: GENETIC PARAMETERS FOR FINE MILK COMPONENTS

Table 1. Descriptive statistics of the mid-infrared (MIR)-predicted lactoferrin $\left(\mathrm{LF}_{\mathrm{MIR}}\right)$; MIR-predicted milk fat globule size $\left(\mathrm{MFGS}_{\mathrm{MIR}}\right)$; milk, fat, and protein yield (kg); fat and protein percentage; and SCS

\begin{tabular}{lrrrrr}
\hline Trait & \multicolumn{1}{c}{ No. } & \multicolumn{1}{c}{ Mean } & \multicolumn{1}{c}{ SD } & Minimum & Maximum \\
\hline LF $_{\text {MIR }}($ log-transformed $)$ & 109,029 & 1.49 & 0.19 & 0.64 & 2.66 \\
MFGS MIR $(\mu \mathrm{m})$ & 109,212 & 4.15 & 0.39 & 2.59 & 5.60 \\
Milk yield & 109,029 & 30.59 & 6.49 & 3.00 & 80.00 \\
Fat yield & 109,029 & 1.20 & 0.26 & 0.07 & 3.78 \\
Protein yield & 109,029 & 0.98 & 0.19 & 0.10 & 2.54 \\
Fat percentage & 109,029 & 3.96 & 0.66 & 0.60 & 9.93 \\
Protein percentage & 109,029 & 3.23 & 0.31 & 1.86 & 4.93 \\
SCS & 109,029 & $1,299.73$ & 782.71 & 1.00 & $2,666.00$ \\
\hline
\end{tabular}

in the study by Arnould et al. (2009), who reported a heritability of 0.22 for milk $\mathrm{LF}_{\mathrm{MIR}}$ content using a multitrait mixed model. Similarly, the estimate of heritability for $\mathrm{LF}_{\mathrm{MIR}}$ from 475 cows and 6 breeds was 0.20 (SE $=0.03$ ) in a study by Soyeurt et al. (2007). Gaunt et al. (1980) reported a higher value for heritability of LF (0.44) using the HPLC method; however, their study was performed on 289 cows, and the heritability estimate had a large standard error (0.30). The moderate heritability of the $\mathrm{LF}_{\mathrm{MIR}}$ in the current study supports the possibility of selection for an increased content of LF or predicted LF in bovine milk, as suggested in previous studies (Soyeurt et al., 2007; Arnould et al., 2009).

Daily heritabilities over the lactation for $\mathrm{LF}_{\mathrm{MIR}}$ and MFGS $_{\text {MIR }}$ are shown in Figure 1. Posterior standard deviations for the daily heritability ranged from 0.0004 to 0.0006 for $L_{\mathrm{MIR}}$ and from 0.0005 to 0.0010 for MFGS $_{\text {MIR }}$. In general, the daily heritability for $L_{\text {MIR }}$ showed an increasing trend throughout the whole lactation (Figure 1). From the beginning of lactation until approximately 45 DIM, the heritability estimates of $\mathrm{LF}_{\mathrm{MIR}}$ slightly decreased. This decrease was followed by a gradual increase in heritability until 105 DIM. The trend then remained constant until 275 DIM, which was followed by a sudden increase in heritability at the end of lactation. Riley et al. (2008) mentioned that the concentration of LF increases sharply during mammary involution in dairy cattle. They proposed a regulatory role for LF during early involution through decreasing casein expression and reducing viability of bovine mammary epithelial cells (Riley et al., 2008). Changes in mammary secretion composition during the

Table 2. Daily average heritability $\left(\mathrm{h}^{2}\right)$ estimates and their associated posterior standard deviations (PSD) for the milk mid-infrared (MIR)predicted lactoferrin $\left(\mathrm{LF}_{\mathrm{MIR}}\right)$ and milk MIR-predicted milk fat globule size $\left(\right.$ MFGS $_{\mathrm{MIR}}$ ) over first lactation in Holstein dairy cattle

\begin{tabular}{lcl}
\hline Trait & $\mathrm{h}^{2}$ & PSD \\
\hline LF $_{\text {MIR }}($ log-transformed $)$ & 0.34 & 0.001 \\
MFGS $_{\text {MIR }}(\mu \mathrm{m})$ & 0.46 & 0.006 \\
\hline
\end{tabular}

process of involution may have implications for disease resistance and are required for the gland to develop fully for maximal milk yield in the subsequent lactation (Hurley, 1989). In another study, the content of LF and IgG was shown to be greatest in milk of multiparous cows at the late stage of lactation (Król et al., 2010). The lowest daily heritability for $\mathrm{LF}_{\mathrm{MIR}}$ at 45 to $55 \mathrm{DIM}$ in this study occurred during the peak of a cow's lactation (Jamrozik et al., 1997; Collard et al., 2000), which might be associated with when a cow goes through metabolic changes and mobilization of body reserves to meet the energy requirements for milk production (Bell and Bauman, 1997; Roche et al., 2009; Bjerre-Harpøth et al., 2012). These results may explain the higher daily heritability for $\mathrm{LF}_{\mathrm{MIR}}$ at the end of lactation in the current study, when the daily milk production is at its lowest and the cow is less susceptible to bacterial infections (Figure 1). The estimated additive genetic variances over the length of lactation for $\mathrm{LF}_{\mathrm{MIR}}$ and MFGS $\mathrm{MIR}_{\text {are }}$ shown in Figure 2. The graph indicates that MFGS $\mathrm{SIR}_{\mathrm{M}}$ was more variable throughout lactation compared with $\mathrm{LF}_{\mathrm{MIR}}$. This might be associated with the decrease in the size of the fat globule in milk as lactation advances in the dairy cow (Wiking et al., 2004).

The average heritability throughout lactation for MFGS $_{\text {MIR }}$ from the 2 multivariate analyses is shown in Table 2 and was estimated at 0.46. This estimated value was higher than the value estimated in a previous study by Fleming et al. (2017b), in which the mean estimated heritability for MIR-predicted volume moment mean $(\mathrm{D}[4,3])$ was $0.30(\mathrm{SE}=0.17)$. Fleming et al. (2017b) analyzed only a subset of the records used in the present study, which may explain the variation in estimates. Average heritability direct measures of MFGS were investigated in a limited number of studies using different methodologies and numbers of records. The results of these previous investigations support the idea that the milk MFGS is moderately heritable (Couvreur et al., 2007; Logan et al., 2014).

The graph of daily heritability for MFGS $\mathrm{MIR}_{\mathrm{MI}}$ is shown in Figure 1. Daily heritability for MFGS $\mathrm{MIR}_{\text {was }}$ the lowest during the very first 3 wk of lactation $(\sim 25 \mathrm{DIM})$ 


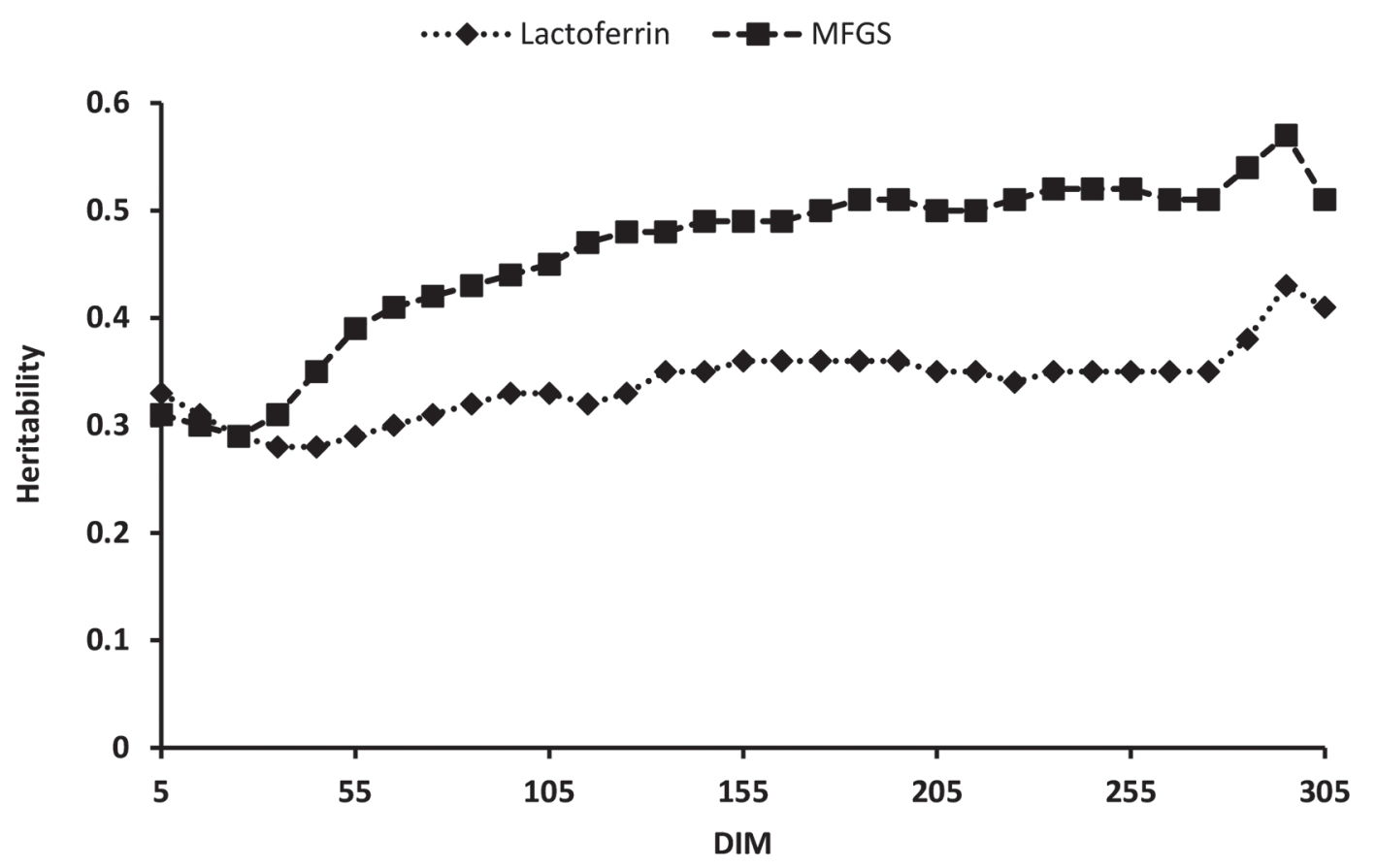

Figure 1. Daily heritability of mid-infrared (MIR)-predicted milk lactoferrin and MIR-predicted milk fat globule size (MFGS) in firstlactation Holstein dairy cows. Posterior SD ranged from 0.000379 to 0.000582 for milk MIR-predicted lactoferrin and from 0.000550 to 0.001021 for milk MIR-predicted MFGS.

and then increased gradually to 55 DIM. This increase in heritability continued steadily until 295 DIM and dropped at the end of the lactation (305 DIM). Bastin et al. (2011) reported that milk fat yield $(\mathrm{kg})$ and fat content $(\mathrm{g} / \mathrm{dL}$ of milk) were more heritable in mid to late lactation (at around 180 DIM) compared with the beginning of milk production in Walloon first-parity Holstein dairy cattle (Bastin et al., 2011).

Several investigations have studied genes that regulate milk fat synthesis and MFGM formation during the lactation cycle in dairy cattle (Bionaz and Loor, 2008; Keenan and Mather, 2009; Mesilati-Stahy et al., 2011; Argov-Argaman et al., 2013). For example, Bionaz and Loor (2008) reported a higher expression of the SREBF2 gene at d 30, with its peak of expression on d 120 postpartum. This gene is primarily involved in cholesterol synthesis, and its higher expression is proposed to be necessary to meet cholesterol requirements for MFGM formation (Bionaz and Loor, 2008). The MFGM is reported to contain a high amount of cholesterol (Keenan and Mather, 2009), which plays an important role in maintaining membrane structure and is critical for many biological processes, including compartmentalizing membrane proteins to modulate their functions (Lee et al., 2018). Another gene, LASS2, has an active effect on MFGM synthesis, with the peak of expression on d 60 postpartum in the bovine mammary gland (Bionaz and Loor, 2008). Taking all this informa- tion together supports the heritability estimate found for MFGS $\mathrm{SIR}_{\mathrm{M}}$ in this study; however, the complete genetic architecture of MFGS still needs to be studied further, as discussed in Fleming et al. (2017b).

A graph of residual variance across lactation is shown in Figure 3. The residual variance for $\mathrm{LF}_{\mathrm{MIR}}$ followed a constant trend throughout lactation with a sudden decline at the end. The residual variance for MFGS $\mathrm{SIR}_{\mathrm{M}}$ was higher early in lactation and then gradually dropped from the middle to the end of lactation. The estimated herd-year of calving and permanent environmental variances are shown in Supplemental Figures S1 and S2 (https://doi.org/10.3168/jds.2019-16850).

\section{Genetic Correlations}

Genetic correlations among the traits examined in this study are shown in Table 3. Posterior standard deviations for all estimates were low $(<0.015)$. A moderate average correlation between $\mathrm{LF}_{\mathrm{MIR}}$ and protein percentage (0.41) and a weaker correlation between $\mathrm{LF}_{\mathrm{MIR}}$ and fat percentage (0.21) were estimated. These results are in good agreement with the findings by Arnould et al. (2009) on bovine milk, in which the correlations between predicted LF and protein and fat percentages were reported to be 0.52 and 0.37 , respectively. The positive correlation between protein percentage and $\mathrm{LF}_{\mathrm{MIR}}$ can be explained by the protein nature of $\mathrm{LF}$ 


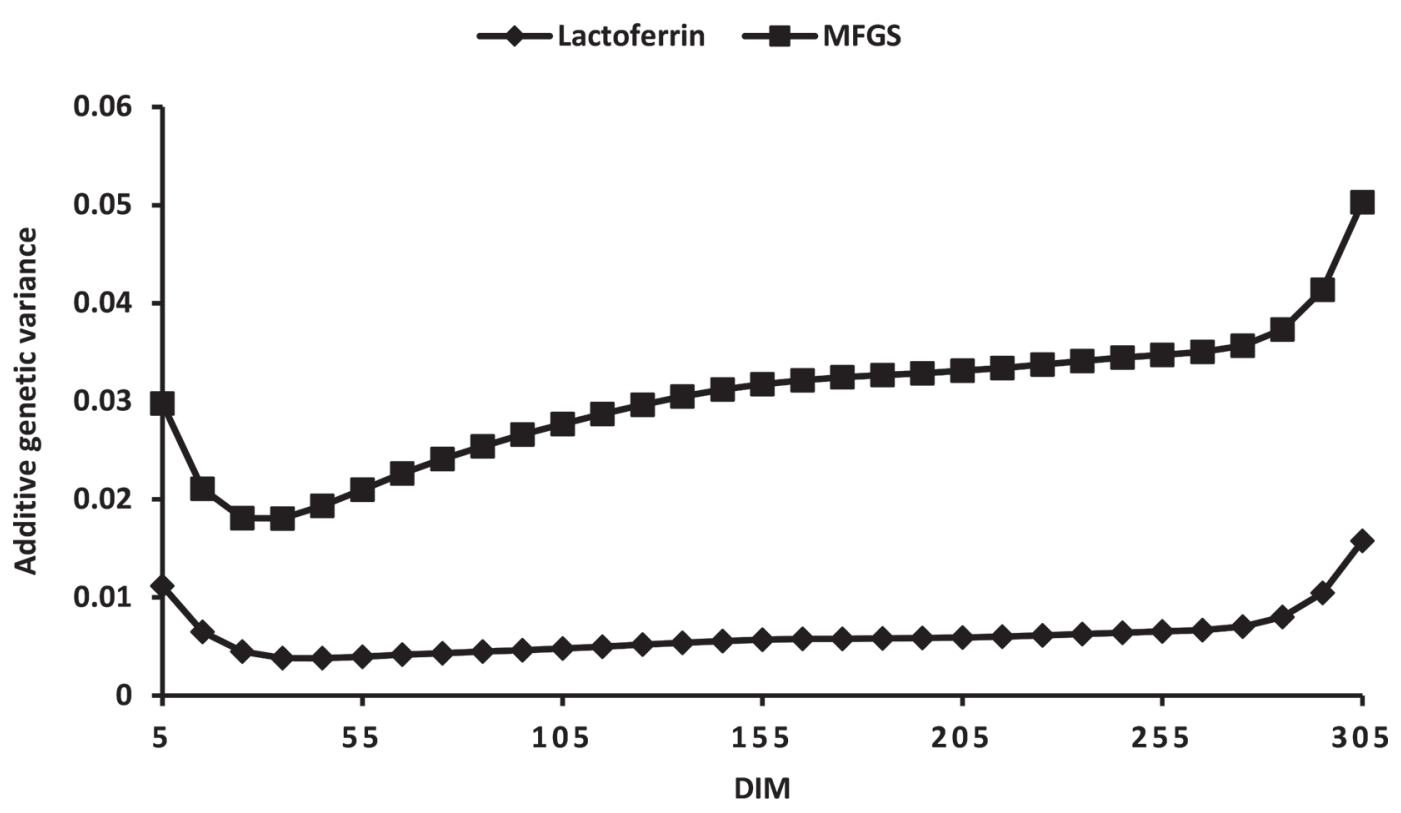

Figure 2. Additive genetic variances over the lactation for mid-infrared (MIR)-predicted milk fat globule size (MFGS) and MIR-predicted milk lactoferrin in first-lactation Holstein cows.

(Arnould et al., 2009). Additionally, the LF gene (LTF) is mapped on chromosome 22 in BTA (BTA22). The presence of markers and QTL on BTA22 that affect protein yield, protein content, casein percentage, and fat percentage in bovine milk has been reported in several studies (Rodriguez-Zas et al., 2002; Ashwell et al., 2004; Buitenhuis et al., 2016). The average daily correlation among $\mathrm{LF}_{\mathrm{MIR}}$ and other examined traits over the lactation is shown in Figure 4. Figure 4a shows that the correlations between $\mathrm{LF}_{\mathrm{MIR}}$ and protein and fat percentage increased as the cows advanced through lactation. The average genetic correlation between $\mathrm{LF}_{\mathrm{MIR}}$ and milk yield was weak and negative $(-0.16)$. This result was in agreement with the estimate $(-0.25)$ reported by Arnould et al. (2009) and possibly can be explained by a dilution effect. Daily genetic correlations in Figure $4 \mathrm{a}$ and $\mathrm{b}$ exhibited a weak and positive correlation between $\mathrm{LF}_{\mathrm{MIR}}$ and milk yield during the first weeks of lactation; the correlation then became negative and moderate as lactation continued ( -0.32 at 305 DIM). Cheng et al. (2008) also reported that LF concentration in bovine milk was significantly correlated with the stage of lactation $(\mathrm{r}=0.56 ; P<0.001)$ and daily milk production $(\mathrm{r}=-0.48 ; P<0.001)$. They indicated that the milk LF concentration (log-transformed) is at its highest at the late period of lactation (201 d from parturition to the end of lactation) and when daily milk production is less than $20 \mathrm{~kg}$ (Cheng et al., 2008).

Across the lactation, the average genetic correlation between $\mathrm{LF}_{\mathrm{MIR}}$ and SCS was close to zero (0.06; Table 3). Soyeurt et al. (2007) reported a similar genetic cor- relation (0.04) for $\mathrm{LF}_{\mathrm{MIR}}$ and SCS, whereas Cheng et al. (2008) found a genetic correlation of 0.38 between ELISA-measured LF concentration and SCC. Arnould et al. (2009) also found a stronger genetic correlation (0.24) between LF $_{\text {MIR }}$ and SCS compared with this study. Average daily genetic correlations between $\mathrm{LF}_{\mathrm{MIR}}$ and SCS are shown in Figure 4a and b. Figure 4 shows that $\mathrm{LF}_{\mathrm{MIR}}$ and SCS had a positive correlation during the first days of lactation (0.16); the correlation declined and remained zero or negative until approximately 105 DIM. Then, there was a gradual positive increase in the correlation ( 0.16 to 0.18$)$ followed by a sudden decline (0.05 to 0.01) on d 255 and subsequent increase at the end of lactation (0.11). This increase in correlation in early lactation and end of lactation might be associated with the higher susceptibility of cows to bacterial infections at the beginning and end of lactation before the dry period (Smith et al., 1985; Bradley et al., 2015).

Lactoferrin has been proposed to play an important role in mammary gland immunity and defense against mastitis pathogens (Sordillo et al., 1997). In addition, as a part of the involution process, after the cessation of milking, the concentration of natural protective factors such as LF increases (Smith et al., 1985; Sordillo et al., 1987; Hurley, 1989). This supports the increase in the genetic correlation between $\mathrm{LF}_{\mathrm{MIR}}$ and SCS at the end of lactation, as was observed in the current study. A limited number of studies have investigated the daily variation in genetic correlation between SCS and LF. However, considering the protein nature of LF 


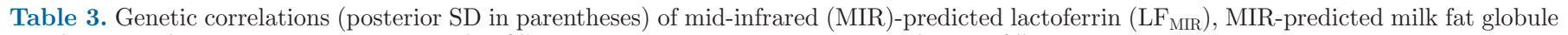
size $\left(\right.$ MFGS $_{\mathrm{MIR}}$ ), fat yield, fat percentage (Fat\%), protein yield, protein percentage (Protein\%), and SCS

\begin{tabular}{lcccrrr}
\hline Trait & Milk yield & Fat yield & Fat\% & Protein yield & Protein\% \\
\hline LF $_{\text {MIR }}$ & $-0.163(0.002)$ & $0.067(0.002)$ & $0.211(0.001)$ & $0.081(0.003)$ & $0.411(0.001)$ & $0.064(0.014)$ \\
MFGS $_{\text {MIR }}$ & $-0.209(0.002)$ & $0.373(0.002)$ & $0.532(0.001)$ & $-0.184(0.002)$ & $0.081(0.001)$ & $-0.078(0.009)$ \\
\hline
\end{tabular}

and the moderate correlation between SCS and protein percentage in this study, one could anticipate that the correlation between SCS and LF would follow a pattern similar to that of the correlation between the protein percentage and LF. Dadpasand et al. (2013) reported a similar genetic correlation between SCS and protein percentage (0.08) on d 200 and 350 in lactation in Holsteins. Interactions among factors during lactation may also affect the changes in LF concentrations in cows that show no signs of clinical mastitis (Cheng et al., 2008). Litwińczuk et al. (2011) also mentioned that an increase in SCC induces an increase in immunoactive proteins, including LF and lysozyme in bovine milk (Litwińczuk et al., 2011). Because SCC increases with mastitis, the result of this study may indicate that $\mathrm{LF}_{\mathrm{MIR}}$ can potentially be used as an indicator of mastitis, similar to what was discussed in Soyeurt et al. (2007).
Average genetic correlations among MFGS $_{\mathrm{MIR}}$, milk and fat yield, fat percentage, and SCS are shown in Table 3. Average genetic correlations with $\mathrm{MFGS}_{\mathrm{MIR}}$ were $-0.20,0.37$, and 0.53 for milk yield, fat yield, and fat percentage, respectively. Posterior standard deviations for all estimates were low $(<0.01)$. The average genetic correlation between MFGS $_{\mathrm{MIR}}$ and fat percentage in this study (0.53) was found to be more similar to the average correlation between $\mathrm{D}[4,3]$ and fat percentage (0.54) than the correlation between MIR-predicted $\mathrm{D}[4,3]$ and fat percentage (0.97) reported previously by Fleming et al. (2017b). Additionally, standard deviations estimated for the correlations of MFGS $\mathrm{MIR}_{\mathrm{M}}$ with fat percentage and other milk components were significantly lower in this study than the ones reported previously by Fleming et al. (2017b), who used records from 254 cows in 29 herds. Therefore, one could speculate that the prediction equation generated by Fleming et

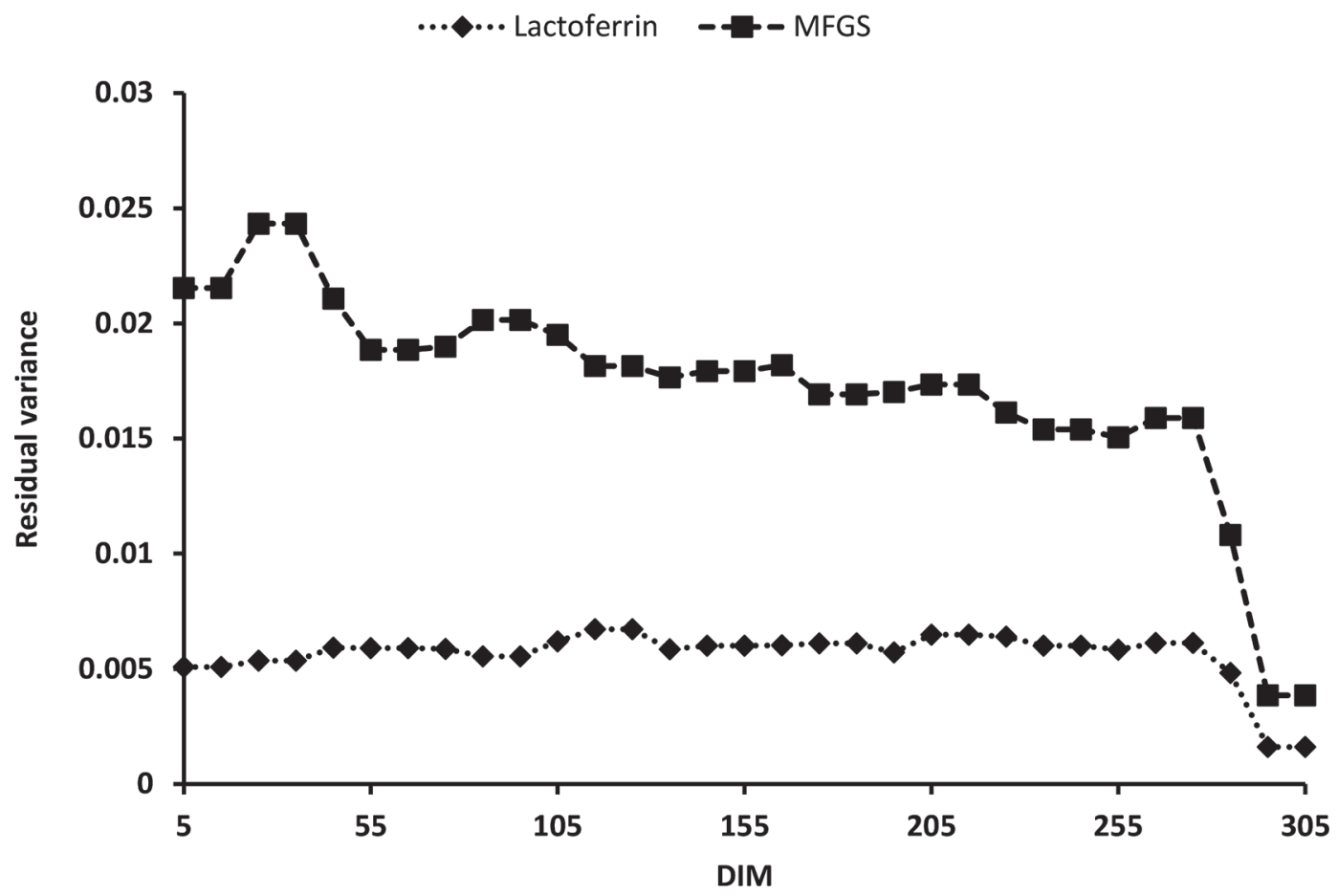

Figure 3. Residual variance over first lactation for mid-infrared (MIR)-predicted milk lactoferrin and MIR-predicted milk fat globule size (MFGS) in Holstein dairy cows. 

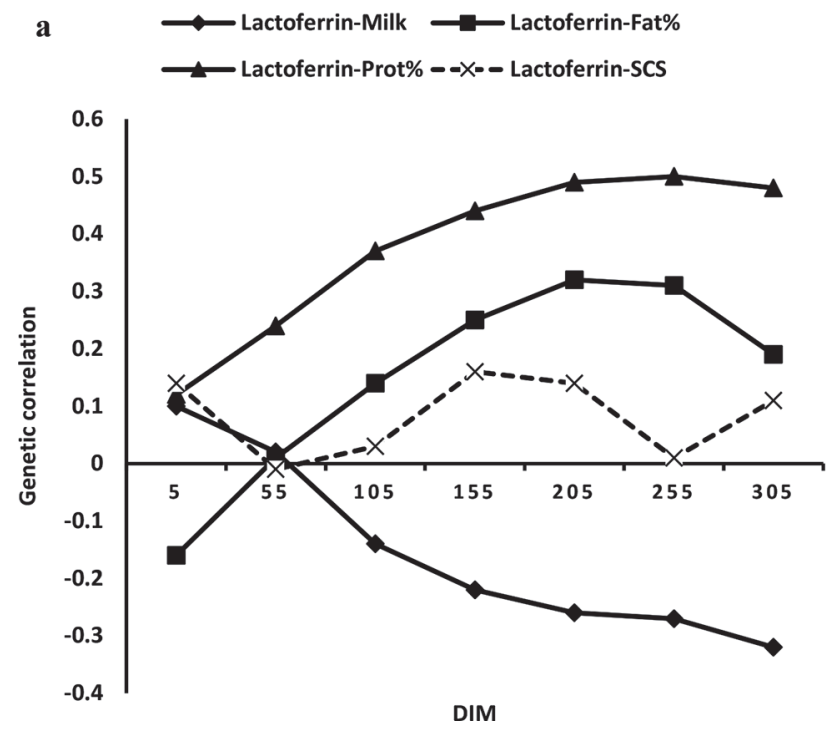
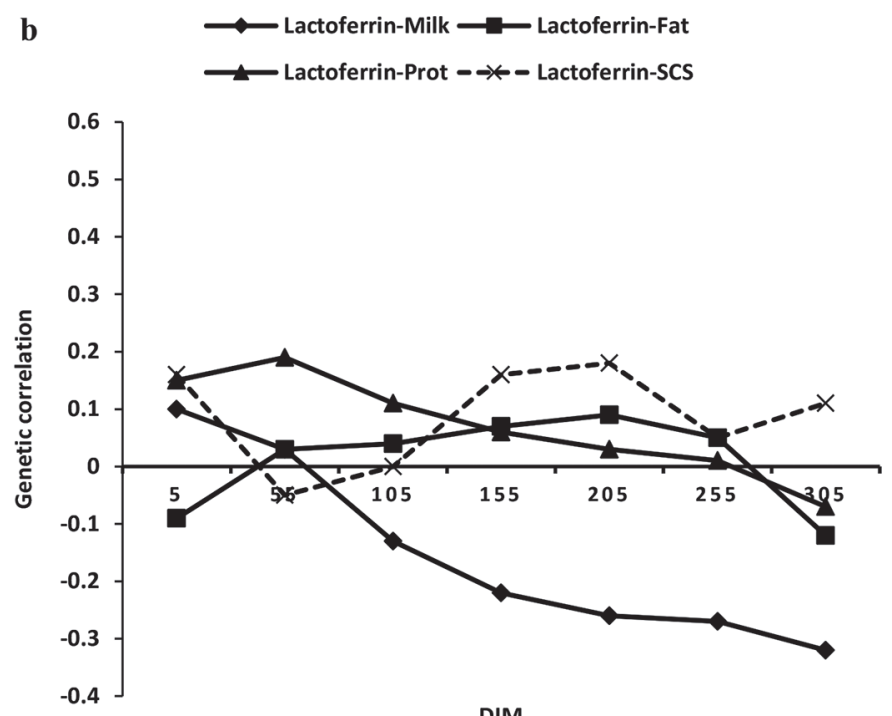

Figure 4. (a) Daily genetic correlations between mid-infrared (MIR)-predicted lactoferrin and milk yield, MIR-predicted lactoferrin and fat and protein percentages (Fat\% and Prot\%, respectively), and MIR-predicted lactoferrin and SCS. (b) Daily genetic correlations between MIRpredicted lactoferrin and milk yield, MIR-predicted lactoferrin and fat and protein yields, and MIR-predicted lactoferrin and SCS.

al. (2017b) was less dependent on utilizing the indirect correlation with milk fat content in the current study with more data.

The current study did not investigate the genetic cor-

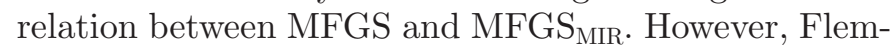
ing et al. (2017b) found a strong genetic correlation between the measured and MIR-predicted MFGS (from 0.68 to 0.76 ) and suggested the possibility of selecting animals for MFGS based on the MIR-predicted MFGS values in milk (Fleming et al., 2017b).

The average daily correlations between MFGS $_{\mathrm{MIR}}$ and fat percentage and fat yield are shown in Figures $5 \mathrm{a}$ and b, respectively. Daily genetic correlations between MFGS $_{\text {MIR }}$ and fat yield were positive (0.29) at the beginning of lactation, then increased up to 0.42 at 155 DIM. The correlation between MFGS $_{\text {MIR }}$ and fat yield remained constant, with a very slow drop in value (0.34) toward the end of lactation. Daily correlations between $\mathrm{MFGS}_{\mathrm{MIR}}$ and fat percentage were moderate and positive throughout the whole lactation (Figure $5 \mathrm{a})$. This is in agreement with previous studies; for instance, Gantner et al. (2015) reported that MFGS was correlated with milk fat content regardless of the species (Gantner et al., 2015). Wiking et al. (2004) also reported a positive correlation (0.54) between the average diameter of the MFG and diurnal fat yield in the milk of Danish Holstein cows. Their study indicated a decrease in MFGS as the lactation advanced (Wiking et al., 2004). Bastin et al. (2011) indicated that there is a strong correlation between fat percentage and MUFA and PUFA in bovine milk (Bastin et al., 2011). The bovine MFGM is mostly made up of MUFA and PUFA (Jensen and Nielsen, 1996; Martini et al., 2013, 2017). Analysis of fatty acid composition demonstrated a positive genetic correlation between the content of stearic, palmitic, palmitoleic, and oleic acids in milk and the average diameter of MFG (Wiking et al., 2004), and oleic acid (C18:1) was shown to be one of the most frequently occurring MUFA in the MFGM (Martini et al., 2017). This might be associated with the metabolism, energy status, and the ability of high-yielding cows to mobilize body fat reserves early in lactation, which can subsequently result in a slightly higher content of C18:1 cis-9 content in the milk (Bastin et al., 2011). Narayana et al. (2017) and Bastin et al. (2011) found that daily heritability of MIR-predicted UFA was lower early in lactation (45 DIM) due to negative energy balance and that heritability increased through the middle and to the end of lactation, when the animal reached positive energy balance.

The average correlations between MFGS $_{\mathrm{MIR}}$ and protein yield and protein percentage were -0.184 and 0.081 , respectively. This result differed from the values reported by Fleming et al. (2017b), in which the genetic correlation between $\mathrm{D}[4,3]$ and protein percentage was shown to be $0.34 \pm 0.30$. The difference might be associated with the high uncertainty (standard error) in Fleming et al. (2017b). The average correlation between MFGS $\mathrm{S}_{\mathrm{MIR}}$ and SCS was close to zero and negative $(-0.073$; Table 3$)$. Daily average genetic correlations 

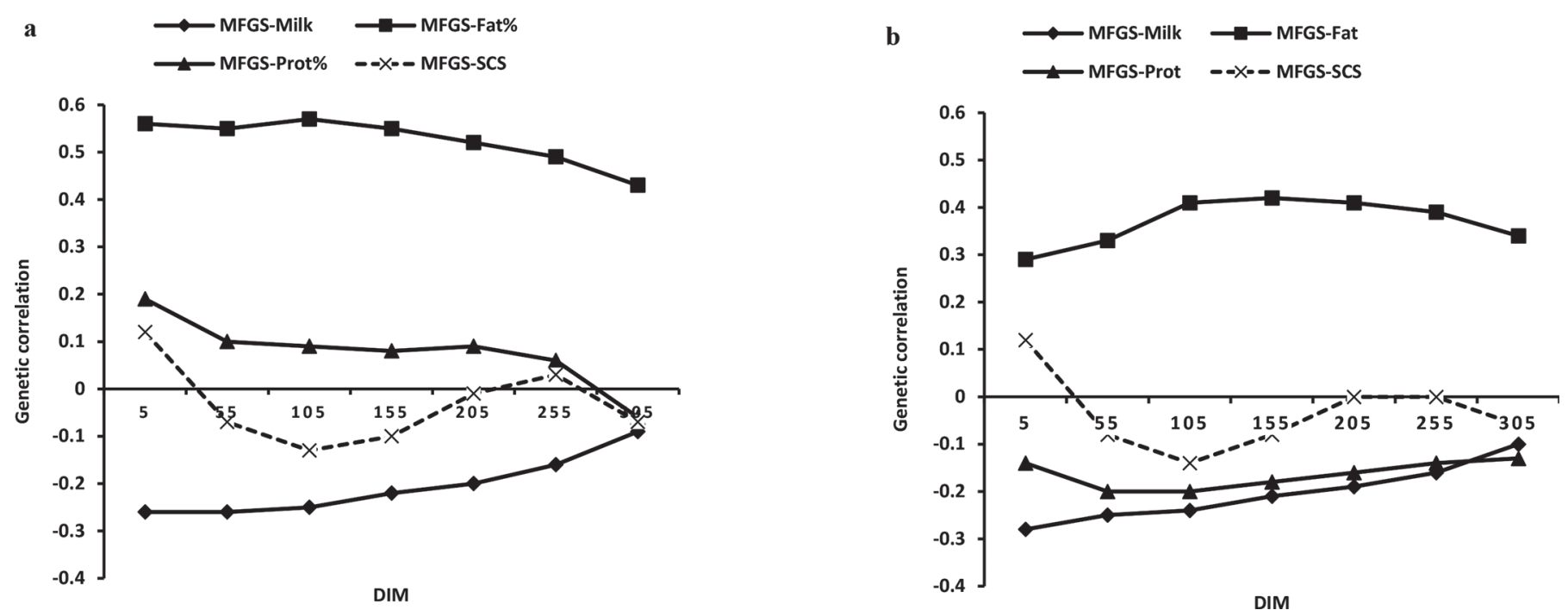

Figure 5. (a) Daily genetic correlations between mid-infrared (MIR)-predicted milk fat globule size (MFGS) and milk yield, MIR-predicted MFGS and fat and protein percentages (Fat\% and Prot\%, respectively), and MIR-predicted MFGS and SCS. (b) Daily genetic correlations between MIR-predicted MFGS and milk yield, MIR-predicted MFGS and fat and protein yields, and MIR-predicted MFGS and SCS.

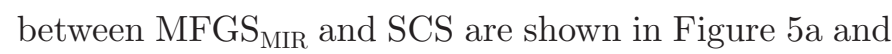
b. The correlation between MFGS $\mathrm{MIR}_{\text {and }}$ SCS varied throughout the lactation but was very close to zero.

Average permanent environment and herd-year correlations among $\mathrm{LF}_{\mathrm{MIR}}$ and $\mathrm{MFG}_{\mathrm{MIR}}$ and milk, fat yield, protein yield, fat percentage, protein percentage, and SCS are shown in Supplemental Tables S1 and S2 (https://doi.org/10.3168/jds.2019-16850). They show a moderate permanent environment and herd-year correlation between predicted MFGS and fat percentage and between predicted LF and protein percentage, suggesting again that MIR prediction for MFGS and LF is not solely a function of the fat and protein percentage in the milk.

The MIR-based proxies for LF and MFGS $\left(\mathrm{LF}_{\mathrm{MIR}}\right.$ and MFGS $\left._{\mathrm{MIR}}\right)$ are moderately heritable. Therefore, under the hypothesis that these indicators have adequate genetic correlations to reference traits LF and MFGS, it may be possible to genetically select for animals with better milk nutritional quality and technological properties by putting selection pressure on these indicator traits. The moderate genetic correlations between predicted MFGS and fat percentage and between predicted LF and protein percentage suggest that MIR predictions for MFGS and LF may not be solely related to fat and protein percentage, respectively, and therefore the prediction equations are not simply predicting fat or protein percentage in the milk. Thus, these MIR-predicted indicator traits may provide additional information for selecting for fine milk components in Holstein cattle.

\section{CONCLUSIONS}

In this study, moderate heritabilities for MIR-predicted LF and MFGS were estimated. Based on these estimates and the previously reported moderate prediction accuracies for $\mathrm{LF}_{\mathrm{MIR}}$ and MFGS $\mathrm{SIR}_{\mathrm{MI}}$, one could suggest that MIR-predicted values could be used for selecting Holstein cattle for these 2 fine milk components. The moderate genetic correlations between MFGS $\mathrm{SIR}_{\mathrm{MI}}$ and fat percentage and between predicted $\mathrm{LF}_{\mathrm{MIR}}$ and protein percentage also suggest that MIR predictions for MFGS and LF are not merely related to fat and protein percentage in the milk and, thus, their prediction equations are not simply predicting fat or protein percentage in the milk.

\section{ACKNOWLEDGMENTS}

All dairy producers participating to this project are gratefully acknowledged. We warmly acknowledge Ian Rumbles [now at Dairy Record Management System (DRMS), Raleigh, NC] and all of the CanWest DHI team (Guelph, ON, Canada) as well as Daniel Lefebvre and the full team at Valacta (Ste-Anne-de-Bellevue, QC, Canada) for kindly organizing the selection of herds and collecting samples for the project. This study was partly funded by the DairyGen council of the Canadian Dairy Network (Guelph, ON, Canada) and the Natural Sciences and Engineering Research Council of Canada (Ottawa, ON, Canada). This project was also partly supported by Agriculture and Agri-Food Canada (Ot- 
tawa, ON) and by additional contributions from Dairy Farmers of Canada (Ottawa, ON), the Canadian Dairy Network, and the Canadian Dairy Commission under the Agri-Science Clusters Initiative (Ottawa, ON). We warmly acknowledge Foss (Hillerød, Denmark) for partial funding and technical support. The authors have not stated any conflicts of interest.

\section{REFERENCES}

Ali, A. K. A., and G. E. Shook. 1980. An optimum transformation for somatic cell concentration in milk. J. Dairy Sci. 63:487-490. https: //doi.org/10.3168/jds.S0022-0302(80)82959-6.

Argov-Argaman, N., K. Mida, B.-C. Cohen, M. Visker, and K. Hettinga. 2013. Milk fat content and DGAT1 genotype determine lipid composition of the milk fat globule membrane. PLoS One 8:e68707. https://doi.org/10.1371/journal.pone.0068707.

Arnould, V. M.-R., H. Soyeurt, N. Gengler, F. G. Colinet, M. V. Georges, C. Bertozzi, D. Portetelle, and R. Renaville. 2009. Genetic analysis of lactoferrin content in bovine milk. J. Dairy Sci. 92:2151-2158. https://doi.org/10.3168/jds.2008-1255.

Ashwell, M. S., D. W. Heyen, T. S. Sonstegard, C. P. Van Tassell, Y. Da, P. M. VanRaden, M. Ron, J. I. Weller, and H. A. Lewin. 2004. Detection of quantitative trait loci affecting milk production, health, and reproductive traits in Holstein cattle. J. Dairy Sci. 87:468-475. https://doi.org/10.3168/jds.S0022-0302(04)73186-0.

Bastin, C., N. Gengler, and H. Soyeurt. 2011. Phenotypic and genetic variability of production traits and milk fatty acid contents across days in milk for Walloon Holstein first-parity cows. J. Dairy Sci. 94:4152-4163. https://doi.org/10.3168/jds.2010-4108.

Bell, A. W., and D. E. Bauman. 1997. Adaptations of glucose metabolism during pregnancy and lactation. J. Mammary Gland Biol. Neoplasia 2:265-278. https://doi.org/10.1023/A:1026336505343.

Bellamy, W., M. Takase, K. Yamauchi, H. Wakabayashi, K. Kawase, and M. Tomita. 1992. Identification of the bactericidal domain of lactoferrin. Biochim. Biophys. Acta 1121:130-136. https://doi .org/10.1016/0167-4838(92)90346-f.

Bionaz, M., and J. J. Loor. 2008. Gene networks driving bovine milk fat synthesis during the lactation cycle. BMC Genom. 9:366. https: //doi.org/10.1186/1471-2164-9-366.

Bjerre-Harpøth, V., N. C. Friggens, V. M. Thorup, T. Larsen, B. M. Damgaard, K. L. Ingvartsen, and K. M. Moyes. 2012. Metabolic and production profiles of dairy cows in response to decreased nutrient density to increase physiological imbalance at different stages of lactation. J. Dairy Sci. 95:2362-2380. https://doi.org/10 $.3168 /$ jds.2011-4419.

Bonfatti, V., G. Di Martino, and P. Carnier. 2011. Effectiveness of mid-infrared spectroscopy for the prediction of detailed protein composition and contents of protein genetic variants of individual milk of Simmental cows. J. Dairy Sci. 94:5776-5785. https://doi .org/10.3168/jds.2011-4401.

Bonfatti, V., A. Fleming, A. Koeck, and F. Miglior. 2017. Standardization of milk infrared spectra for the retroactive application of calibration models. J. Dairy Sci. 100:2032-2041. https://doi.org/ $10.3168 /$ jds.2016-11837.

Bradley, A. J., S. De Vliegher, M. J. Green, P. Larrosa, B. Payne, E. S. van de Leemput, O. Samson, D. Valckenier, T. Van Werven, H. W. F. Waldeck, V. White, and L. Goby. 2015. An investigation of the dynamics of intramammary infections acquired during the dry period on European dairy farms. J. Dairy Sci. 98:6029-6047. https: //doi.org/10.3168/jds.2014-8749.

Buitenhuis, B., N. A. Poulsen, G. Gebreyesus, and L. B. Larsen. 2016. Estimation of genetic parameters and detection of chromosomal regions affecting the major milk proteins and their post translational modifications in Danish Holstein and Danish Jersey cattle. BMC Genet. 17:114. https://doi.org/10.1186/s12863-016-0421-2.

Cheng, J. B., J. Q. Wang, D. P. Bu, G. L. Liu, C. G. Zhang, H. Y. Wei, L. Y. Zhou, and J. Z. Wang. 2008. Factors affecting the lactoferrin concentration in bovine milk. J. Dairy Sci. 91:970-976. https://doi .org $/ 10.3168 /$ jds.2007-0689.

Collard, B. L., P. J. Boettcher, J. C. M. Dekkers, D. Petitclerc, and L. R. Schaeffer. 2000. Relationships between energy balance and health traits of dairy cattle in early lactation. J. Dairy Sci. 83:2683-2690. https://doi.org/10.3168/jds.S0022-0302(00)75162 $-9$.

Couvreur, S., C. Hurtaud, P. G. Marnet, P. Faverdin, and J. L. Peyraud. 2007. Composition of milk fat from cows selected for milk fat globule size and offered either fresh pasture or a corn silage-based diet. J. Dairy Sci. 90:392-403. https://doi.org/10.3168/jds.S0022 -0302(07)72640-1.

Dadpasand, M., M. Zamiri, and H. Atashi. 2013. Genetic correlation of average somatic cell score at different stages of lactation with milk yield and composition in Holstein cows. Majallah-i Tahqiqat-i Dampizishki-i Iran 14:190-196.

De Marchi, M., V. Toffanin, M. Cassandro, and M. Penasa. 2014. Invited review: Mid-infrared spectroscopy as phenotyping tool for milk traits. J. Dairy Sci. 97:1171-1186. https://doi.org/10.3168/ jds.2013-6799.

de Roos, A. P. W., H. J. C. M. van den Bijgaart, J. Hørlyk, and G. de Jong. 2007. Screening for subclinical ketosis in dairy cattle by Fourier transform infrared spectrometry. J. Dairy Sci. 90:1761-1766. https://doi.org/10.3168/jds.2006-203.

Duarte, D. C., A. Nicolau, J. A. Teixeira, and L. R. Rodrigues. 2011. The effect of bovine milk lactoferrin on human breast cancer cell lines. J. Dairy Sci. 94:66-76. https://doi.org/10.3168/jds.2010 -3629 .

Fleming, A., F. S. Schenkel, R. A. Ali, M. Corredig, S. Carta, C. M. Gregu, F. Malchiodi, N. P. P. Macciotta, and F. Miglior. 2018. Phenotypic investigation of fine milk components in bovine milk and their prediction using mid-infrared spectroscopy. Can. J. Anim. Sci. 99:218-227.

Fleming, A., F. S. Schenkel, J. Chen, F. Malchiodi, R. A. Ali, B. Mallard, M. Sargolzaei, M. Corredig, and F. Miglior. 2017a. Variation in fat globule size in bovine milk and its prediction using mid-infrared spectroscopy. J. Dairy Sci. 100:1640-1649. https://doi.org/ 10.3168/jds.2016-11427.

Fleming, A., F. S. Schenkel, A. Koeck, F. Malchiodi, R. A. Ali, M. Corredig, B. Mallard, M. Sargolzaei, and F. Miglior. 2017b. Heritabilities of measured and mid-infrared predicted milk fat globule size, milk fat and protein percentages, and their genetic correlations. J. Dairy Sci. 100:3735-3741. https://doi.org/10.3168/jds .2016-12243.

Gantner, V., P. Mijić, M. Baban, Z. Škrtić, and A. Turalija. 2015. The overall and fat composition of milk of various species. Mljekarstvo 65:223-231. https://doi.org/10.15567/mljekarstvo.2015.0401.

Gaunt, S. N., N. Raffio, E. T. Kingsbury, R. A. Damon, W. H. Johnson, and B. A. Mitchell. 1980. Variation of lactoferrin and mastitis and their heritabilities. J. Dairy Sci. 63:1874-1880. https://doi .org/10.3168/jds.S0022-0302(80)83154-7.

Hurley, W. L. 1989. Mammary gland function during involution. J. Dairy Sci. 72:1637-1646. https://doi.org/10.3168/jds.S0022 -0302(89)79276-6.

Jamrozik, J., L. R. Schaeffer, and J. C. M. Dekkers. 1997. Genetic evaluation of dairy cattle using test day yields and random regression model. J. Dairy Sci. 80:1217-1226. https://doi.org/10.3168/ jds.S0022-0302(97)76050-8.

Jamrozik, J., L. R. Schaeffer, and K. A. Weigel. 2002. Estimates of genetic parameters for single- and multiple-country test-day models. J. Dairy Sci. 85:3131-3141. https://doi.org/10.3168/jds.S0022 $-0302(02) 74401-9$

Jensen, S. K., and K. N. Nielsen. 1996. Tocopherols, retinol, betacarotene and fatty acids in fat globule membrane and fat globule core in cows' milk. J. Dairy Res. 63:565-574. https://doi.org/10 $.1017 / \mathrm{s} 0022029900032106$.

Kaminski, S., K. Olenski, P. Brym, T. Malewski, and A. A. Sazanov. 2006. Single nucleotide polymorphism in the promoter region of the lactoferrin gene and its associations with milk performance traits in Polish Holstein-Friesian cows. Anim. Genet. 42:924-927. https://doi.org/10.1134/S1022795406080114. 
Keenan, T. W., and I. H. Mather. 2009. Intracellular origin of milk fat globules and the nature of the milk fat globule membrane. Adv. Dairy Chem. 2:137-171. https://doi.org/10.1007/0-387-28813-9_4.

Król, J., Z. Litwińczuk, A. Brodziak, and J. Barłowska. 2010. Lactoferrin, lysozyme and immunoglobulin G content in milk of four breeds of cows managed under intensive production system. Pol. J. Vet. Sci. 13:357-361.

Lee, H., E. Padhi, Y. Hasegawa, J. Larke, M. Parenti, A. Wang, O. Hernell, B. Lönnerdal, and C. Slupsky. 2018. Compositional dynamics of the milk fat globule and its role in infant development. Front Pediatr. 6:313. https://doi.org/10.3389/fped.2018.00313.

Legrand, D., E. Elass, M. Carpentier, and J. Mazurier. 2005. Lactoferrin: A modulator of immune and inflammatory responses. Cell. Mol. Life Sci. 62:2549-2559. https://doi.org/10.1007/s00018-005 $-5370-2$.

Litwińczuk, Z., J. Król, A. Brodziak, and J. Barłowska. 2011. Changes of protein content and its fractions in bovine milk from different breeds subject to somatic cell count. J. Dairy Sci. 94:684-691. https://doi.org/10.3168/jds.2010-3217.

Logan, A., M. Auldist, J. Greenwood, and L. Day. 2014. Natural variation of bovine milk fat globule size within a herd. J. Dairy Sci. 97:4072-4082. https://doi.org/10.3168/jds.2014-8010.

Martini, M., I. Altomonte, and F. Salari. 2013. Evaluation of the fatty acid profile from the core and membrane of fat globules in ewe's milk during lactation. Lebensm. Wiss. Technol. 50:253-258. https: //doi.org/10.1016/j.lwt.2012.05.019.

Martini, M., I. Altomonte, A. M. Sant'Ana Da Silva, and F. Salari. 2017. Fatty acid composition of the bovine milk fat globules obtained by gravity separation. Int. Food Res. J. 24:148-152.

Martini, M., C. Scolozzi, F. Cecchi, M. Mele, and F. Salari. 2008. Relationship between morphometric characteristics of milk fat globules and the cheese making aptitude of sheep's milk. Small Rumin. Res. 74:194-201. https://doi.org/10.1016/j.smallrumres.2007.07.001.

McParland, S., G. Banos, E. Wall, M. P. Coffey, H. Soyeurt, R. F. Veerkamp, and D. P. Berry. 2011. The use of mid-infrared spectrometry to predict body energy status of Holstein cows. J. Dairy Sci. 94:3651-3661. https://doi.org/10.3168/jds.2010-3965.

McParland, S., E. Kennedy, E. Lewis, S. G. Moore, B. McCarthy, M. O'Donovan, and D. P. Berry. 2015. Genetic parameters of dairy cow energy intake and body energy status predicted using midinfrared spectrometry of milk. J. Dairy Sci. 98:1310-1320. https:/ /doi.org/10.3168/jds.2014-8892.

Mesilati-Stahy, R., K. Mida, and N. Argov-Argaman. 2011. Size-dependent lipid content of bovine milk fat globule and membrane phospholipids. J. Agric. Food Chem. 59:7427-7435. https://doi .org/10.1021/jf201373j.

Narayana, S. G., F. S. Schenkel, A. Fleming, A. Koeck, F. Malchiodi, J. Jamrozik, J. Johnston, M. Sargolzaei, and F. Miglior. 2017. Genetic analysis of groups of mid-infrared predicted fatty acids in milk. J. Dairy Sci. 100:4731-4744. https://doi.org/10.3168/jds .2016-12244.

Pan, Y., M. Rowney, P. Guo, P. Hobman, and M. Goulburn. 2007. Biological properties of lactoferrin: An overview. Aust. J. Dairy Technol. 62:31-42.

Rainard, P., and C. Riollet. 2006. Innate immunity of the bovine mammary gland. Vet. Res. 37:369-400. https://doi.org/10.1051/vetres: 2006007.

Reinhardt, T. A., and J. D. Lippolis. 2006. Bovine milk fat globule membrane proteome. J. Dairy Res. 73:406-416. https://doi.org/10 $.1017 /$ S0022029906001889.

Riley, L. G., P. Williamson, P. C. Wynn, and P. A. Sheehy. 2008. Lactoferrin decreases primary bovine mammary epithelial cell viability and casein expression. J. Dairy Res. 75:135-141. https:// doi.org/10.1017/S0022029907002920.

Roche, J. R., N. C. Friggens, J. K. Kay, M. W. Fisher, K. J. Stafford, and D. P. Berry. 2009. Invited review: Body condition score and its association with dairy cow productivity, health, and welfare. J. Dairy Sci. 92:5769-5801. https://doi.org/10.3168/jds.2009-2431.
Rodriguez-Zas, S. L., B. R. Southey, D. W. Heyen, and H. A. Lewin. 2002. Detection of quantitative trait loci influencing dairy traits using a model for longitudinal data. J. Dairy Sci. 85:2681-2691. https://doi.org/10.3168/jds.S0022-0302(02)74354-3.

Rutten, M. J. M., H. Bovenhuis, K. A. Hettinga, H. J. F. Van Valenberg, and J. A. M. Van Arendonk. 2009. Predicting bovine milk fat composition using infrared spectroscopy based on milk samples collected in winter and summer. J. Dairy Sci. 92:6202-6209. https: //doi.org/10.3168/jds.2009-2456.

Smith, K., D. A. Todhunter, and P. S. Schoenberger. 1985. Environmental pathogens and intramammary infection during the dry period. J. Dairy Sci. 68:402-417. https://doi.org/10.3168/jds.s0022 $-0302(85) 80838-9$

Smoczyński, M., B. Staniewski, and K. Kiełczewska. 2012. Composition and structure of the bovine milk fat globule membrane- Some nutritional and technological implications. Food Rev. Int. 28:188202. https://doi.org/10.1080/87559129.2011.595024.

Sordillo, L. M., S. C. Nickerson, R. M. Akers, and S. P. Oliver. 1987. Secretion composition during bovine mammary involution and the relationship with mastitis. Int. J. Biochem. 19:1165-1172. https:// doi.org/10.1016/0020-711x(87)90098-x.

Sordillo, L. M., K. Shafer-Weaver, and D. DeRosa. 1997. Immunobiology of the mammary gland. J. Dairy Sci. 80:1851-1865. https:// doi.org/10.3168/jds.S0022-0302(97)76121-6.

Soyeurt, H., F. G. Colinet, V. M.-R. Arnould, P. Dardenne, C. Bertozzi, R. Renaville, D. Portetelle, and N. Gengler. 2007. Genetic variability of lactoferrin content estimated by mid-infrared spectrometry in bovine milk. J. Dairy Sci. 90:4443-4450. https://doi .org/10.3168/jds.2006-827.

Tomita, M., H. Wakabayashi, K. Yamauchi, S. Teraguchi, and H. Hayasawa. 2002. Bovine lactoferrin and lactoferricin derived from milk: Production and applications. Biochem. Cell Biol. 80:109 112. https://doi.org/10.1139/o01-230.

Tsuda, H., T. Kozu, G. Inuma, Y. Ohashi, Y. Saito, D. Saito, T. Akasu, D. B. Alexander, M. Futakuchi, K. Fukamachi, J. Xu, T. Kakizoe, and M. Iigo. 2010. Cancer prevention by bovine lactoferrin: From animal studies to human trial. Biometals 23:399-409. https://doi.org/10.1007/s10534-010-9331-3.

Vannice, G., and H. Rasmussen. 2014. Position of the academy of nutrition and dietetics: Dietary fatty acids for healthy adults. J. Acad. Nutr. Diet. 114:136-153. https://doi.org/10.1016/j.jand .2013.11.001.

Wakabayashi, H., K. Yamauchi, and M. Takase. 2006. Lactoferrin research, technology and applications. Int. Dairy J. 16:1241-1251. https://doi.org/10.1016/j.idairyj.2006.06.013.

Ward, P. P., E. Paz, and O. M. Conneely. 2005. Multifunctional roles of lactoferrin: A critical overview. Cell. Mol. Life Sci. 62:25402548. https://doi.org/10.1007/s00018-005-5369-8.

Weinberg, E. D. 1978. Iron and infection. Microbiol. Rev. 42:45-66. https://doi.org/10.1007/s12185-017-2366-2.

Wiking, L., J. Stagsted, L. Björck, and J. H. Nielsen. 2004. Milk fat globule size is affected by fat production in dairy cows. Int. Dairy J. 14:909-913. https://doi.org/10.1016/j.idairyj.2004.03.005.

\section{ORCIDS}

Shadi Nayeri $\odot$ https://orcid.org/0000-0002-1088-9646 Flavio S. Schenkel ৫ https://orcid.org/0000-0001-8700-0633 Pauline Martin () https://orcid.org/0000-0003-2950-2728 Allison Fleming $\odot$ https://orcid.org/0000-0003-4706-7846 Janusz Jamrozik @ https://orcid.org/0000-0002-6953-6706 Francesca Malchiodi ๑ https://orcid.org/0000-0002-1151-0845 Luiz F. Brito @ https://orcid.org/0000-0002-5819-0922 Christine F. Baes (1) https://orcid.org/0000-0001-6614-8890 Filippo Miglior (ㄴ) https://orcid.org/0000-0003-2345-8842 